\title{
PERJANJIAN POKOK DAN PERJANJIAN HAK TANGGUNGAN DIKAITKAN DENGAN ASAS PELENGKAP
}

\author{
Triana Dewi Seroja ${ }^{*}$, Winda Fitri ${ }^{* *}$ \\ Fakultas Hukum, Universitas Internasional Batam
}

\begin{abstract}
Agreements for mortgages and complementary principles are two important legal issues in the Underwriting Rights Law. As a complement to the existence of an agreement on mortgages, it depends on the main agreement. Hence, its existence must be preceded by a principal agreement.This research uses the legal normative approach. It is a research method conducted by analyzing secondary data and utilizing a analytical descriptive. Based on the results of the analysis, it was found that the Underwriting Agreement preceded by the Principal Agreement could not be legally justified. This is Underwriting Rights are esablished or only have power, if the debt guaranteed by Underwriting Rights already exists. Unlike the case with the burden of mortgages that have been granted in the first credit agreement. It can also be charged to the next credit agreement that will exist in the future. Therefore, the Underwriting Law can be justified because it is in accordance with the complementary principle.
\end{abstract}

Keywords: Principle agreement, aortgages, aomplementary principle.

\begin{abstract}
Abstrak
Perjanjian hak tanggungan dan asas pelengkap merupakan dua permasalahan hukum yang penting dalam UU Hak Tanggungan, sebab sebagai pelengkap keberadaan perjanjian hak tanggungan bergantung pada perjanjian pokoknya. Sehingga keberadaannya harus didahului dengan perjanjian pokok. Penelitian ini menggunakan metode pendekatan yuridis normatif, yaitu metode penelitian hukum yang dilakukan dengan cara meneliti sumber data-data sekunder menggunakan deskriptif analitis. Berdasarkan hasil analisa didapat bahwa perjanjian Hak Tanggungan yang didahului oleh Perjanjian Pokoknya tidak dapat dibenarkan secara hukum. Sebab Hak Tanggungan lahir atau baru memliki daya kerja, bila utang yang dijamin dengan Hak Tanggungan sudah ada. Berbeda halnya dengan pembebanan hak tanggungan yang telah diberikan pada perjanjian kredit pertama namun dapat dibebankan pula pada perjanjian kredit berikutnya yang akan ada di kemudian hari. Hal ini menurut Undang-Undang Hak Tanggungan dapat dibenarkan karena sesuai dengan asas pelengkap itu sendiri.
\end{abstract}

\section{Keywords: Perjanjian, Hak Tanggungan, Asas Pelengkap.}

\section{A. Latar Belakang Masalah}

Dalam hukum positif Indonesia, lembaga jaminan yang dikenal adalah gadai dan hipotik yang diatur dalam Buku II KUHPerdata, hak tanggungan yang diatur

\footnotetext{
* Alamat Korespondensi : triana_dewi_seroja@yahoo.com

Alamat Korespondensi : winda@uib.ac.id
} 
dalam Undang-Undang No. 4 tahun 1996 tentang Hak Tanggungan (selanjutnya disebut dengan UUHT), jaminan fidusia yang diatur dalam Undang- undang No. 42 thun 1999 tentang Jaminan fidusia. Hipotik merupakan jaminan kebendaan untuk benda-benda tidak bergerak. Sedangkan gadai adalah jaminan kebendaan untuk benda-benda bergerak.

Hak Tanggungan yang memberikan jaminan atas benda tidak bergerak terhadap suatu hutang tertentu harus dituangkan dalam perjanjian tertulis. Dalam UndangUndang No. 4 Tahun 1996 tentang Hak Tanggungan perjanjian hak tanggungan harus berbentuk akta otentik, yang disebut Akta Pemberian Hak Tanggungan (APHT), yang dibuat oleh pejabat berwenang yaitu pejabat Pembuat Akta Tanah (PPAT), sebagaimana diatur dalam pasal 10 ayat (2) karena hak tanggungan itu harus didaftarkan kepada Kantor Pertanahan pasal 13 ayat (20 dan ayat (3) UUHT maka pembuatannya harus berupa akta otentik, di mana kekuatan baik dari segi pembuktian maupun keabsahan dan perlindungan hukum terhadap pembuatan akta secara otentik lebih kuat dibandingkan dengan pembuatan akta di bawah tangan. Setiap peraturan perundang-undangan diperlukan adanya suatu asas, karena asas ini yang melandasi atau menjiwai ataupun menghidupi peraturan.

Demikian pula dalam melakukan perjanjian selain memperhatikan ketentuanketentuan yang ada harus juga memperhatikan asas-asas yang terdapat dalam hukum perjanjian pada umumnya, sedangkan telah diuraikan di atas bahwa pemberian hak tanggungan harus dituangkan dalam bentuk perjanjian tertulis, maka dalam melakukan perjanjian hak tanggungan juga harus memperhatikan asas-asas yang terdapat dalam hukum perjanjian. Perjanjian hak tanggungan merupakan perjanjian yang keberadaannya serta hapusnya bergantung pada perjanjian pokoknya yaitu perjanjian hutang-piutang atau kredit, maka dari itu sifat perjanjian hak tanggungan merupakan iceman dan merupakan pelengkap dari perjanjian pokoknya. Sebagai perjanjian pelengkap maka harus memperhatikan asas pelengkap. Menurut Abdul Kadir Muhammad menyatakan bahwa Asas Pelengkap: mengandung arti bahwa ketentuan undang-undang boleh tidak diikuti apabila pihak-pihak menghendaki dan membuat ketentuan-ketentuan sendiri yang menyimpang dari ketentuan undang-undang. Tetapi apabila dalam perjanjian yang mereka buat itu tidak ditentukan lain. Maka berlakulah ketentuan undang-undang. Asas ini hanya mengenal hak dan kewajiban pihak-pihak saja. ${ }^{1}$

Berdasarkan rumusan tersebut di atas dapat diartikan bahwa asas pelengkap merupakan aturan tersendiri dan terpisah yang dibuat oleh para pihak atas kesepakatan para pihak, yang mengatur hal tertentu tentang prestasi atau hak dan kewajiban para pihak yang membuatnya, asas pelengkap merupakan suatu aturan yang berfungsi sebagai pelengkap atau penyempurna dari suatu ketentuan di sini dapat dilihat bahwa sifatnya merupakan ikatan dari suatu aturan yang merupakan aturan induknya atau pokoknya. Misalnya dalam perjanjian, dapat diambil suatu contoh dalam perjanjian utang- piutang, di mana pada pasal 1131 KUHPerdata

\footnotetext{
${ }^{1}$ Abdulkadir Muhammad, S.H., Hukum Perdata Indonesia, PT. Citra Aditya Bakti, Bandung, 1993, hlm 226
} 
menyebutkan bahwa segala kebendaan si berutang menjadi tanggungan untuk segala perikatan seseorang, dalam hal ini perjanjian utang-piutang yang dibuat tunduk dalam ketentuan yang ada dalam buku III KUHPerdata dan hak kebendaan yang menjadi jaminan tunduk pada ketentuan buku II KUHPerdata, sementara perjanjian untuk memberikan jaminan atas kebendaan tersebut merupakan ketentuan terpisah dari perjanjian utang-piutang yang dapat dibuat sendiri oleh para pihak yang mana merupakan bagian tidak terpisahkan dari perjanjian utangpiutang tersebut.

Dengan demikian Hak Tanggungan tidak akan ada bila tidak ada suatu hutang atau kredit yang dijamin pelunasannya, sebagaimana yang disebutkan pada pasal 1131 KUHPerdata. Dalam perjanjian pokoknya harus dimuat tentang adanya janji untuk memberikan Hak Tanggungan dan perjanjian Hak Tanggungan yang nantinya dibuat secara terpisah dari perjanjian pokoknya tersebut merupakan aturan pelengkap dan merupakan bagian tidak terpisahkan dari perjanjian pokoknya. Seperti yang diatur dalam pasal 10 ayat (1) UUHT yang berbunyi sebagai berikut ;

"Pemberian hak Tanggungan di dahului dengan janji untuk memberikan Hak Tanggungan sebagai jaminan pelunasan utang tertentu, yang dituangkan di dalam dan merupakan bagian tak terpisahkan dari perjanjian utang piutang yang bersangkutan atau perjanjian lainnya yang menimbulkan utang tersebut."

Pasal 3 UU Hak Tanggungan menyebutkan bahwa utang yang dijamin pelunasannya dengan Hak Tanggungan dapat berupa utang yang telah ada atau yang telah diperjanjikan dengan jumlah tertentu atau jumlah yang pada saat permohonan eksekusi Hak Tanggungan diajukan dapat ditentukan berdasarkan perjanjian hutang piutang atau perjanjian lain yang menimbulkan hubungan utang piutang yang bersangkutan.

Dalam perkembangannya terdapat jaminan hutang atas dasar perjanjian pokok yang akan ada di kemudian hari. Beberapa pendapat mengemukakan hal tersebut di atas dapat dilakukan, seperti pendapat dari hofmann, L.C ${ }^{2}$

"jaminan kebendaan gadai dan hipotik dapat diberikan untuk menjamin hutang yang akan datang, demikian pula tidak ada halangan bahwa penanggungan diberikan untuk menanggung perikutan yang akan ada (die voor toekomstige verbinternissen is aangegaan...).

Berdasarkan pendapat tersebut di atas dapat disimpulkan bahwa perjanjian pemberian jaminan dapat dilakukan lebih dahulu dari suatu perikatan atau perjanjian pokoknya. Dalam prakteknya apabila ada terjadi, bahwa perjanjian pemberian jaminan dibuat dan ditandatangani lebih dahulu pada perjanjian pokoknya. Yang demikian itu sengaja diisyaratkan oleh kreditur, sebab khawatir, bahwa setelah perjanjian kreditur ditandatangani dan uangnya telah diberikan kepada debitur, kemudian debitur ingkar janji. Untuk memberikan jaminan sebagai pelunasan utangnya. Jadi sekalipun secara teoritis perjanjian jaminan

\footnotetext{
2 Hoffmann, L.C. Het nedrkandsch Verbinteniessen rech, Jilid II, de Bijzondere overeenkomsten, cetakan pertama, J.B. Wolers Groningen, Batavia, 1936, hal. 425
} 
merupakan perjanjian yang hidup dan mati bergantung dari perjanjian pokoknya dan karenanya bisa menimbulkan kesan mempunyai kedudukan yang kurang penting, namun dalam prakteknya ia mempunyai peran yang sangat besar, bahkan sering kali justru perjanjian pokok baru bisa disetujui apabila jaminannya dinilai cukup. Seperti yang terdapat pada klausula perjanjian kredit pada Bank Fama Internasional pada pasal 11 menyebutkan "perjanjian kredit ini tidak akan pernah ada apabila tidak diikuti oleh adanya suatu jaminan dan yang nilai jaminan tersebut mencukupi nilai kredit."

Dalam praktek Bank Fama Internasional di dalam salah satu klausul perjanjian kreditnya menyebutkan bahwa "mengenai pemberian kredit yang telah dan yang akan ada dengan demikian ketentuan bahwa mengenai syarat-syarat dan perjanjian yang akan ada tersebut, pihak kedua (bank) harus memberitahukannya kepada pihak pertama (debitur)". Dari uraian di atas dapat digambarkan bahwa jaminan hak tanggungan yang telah didaftarkan tersebut dapat juga menjadi jaminan bagi perjanjian kredit berikutnya atau yang akan ada. Di sini dapat dilihat bahwa hak tanggungan tersebut telah dibebankan sebagai jaminan kredit berikutnya, hal ini menurut pasal 5 ayat (1) UUHT dapat dibenarkan.

\section{B. Rumusan Masalah}

Dari uraian tersebut di atas dapat dikatakan bahwa Hak Tanggungan dalam perbankan sebagai pembebanan objek jaminan atas benda tidak bergerak milik debitur dapat dibebankan pada lebih dari satu Hak Tanggungan. Apabila melihat dari sifat jaminan kebendaan itu sendiri, suatu jaminan itu lahir dari adanya suatu perikatan atau perjanjian utang-piutang yang dijamin pelunasannya, sehingga keberadaannya sebagai suatu ikutan atau pelengkap dari perjanjian pokoknya, namun bila Hak Tanggungan dikaitkan dengan pendapat-pendapat sebagaimana disebutkan di atas maka terasa janggal, sebab bagaimana Hak Tanggungan akan ada bila perjanjian pokok yang memberikan jaminannya belum ada? Dan bilamana asas pelengkap Hak Tanggungan dapat dilanggar?. Berdasarkan penjelasan-penjelasan di atas, penulis tertarik untuk melakukan penelitian mengenai Hak Tanggungan dan menuangkannya kedalam tiga rumusan permasalahan yaitu:

1. unsur-unsur apa saja yang terdapat dalam Perjanjian Pokok dan Perjanjian Hak Tanggungan?

2. unsur-unsur apa yang terdapat dalam Asas Pelengkap?

3. analisa mengenai kedudukan Perjanjian Hak Tanggungan yang dibuat sebelum Perjanjian Pokok dikaitkan dengan Asas Pelengkap ?

\section{Metode Penelitian}

Penelitian ini sifatnya yuridis normatif dengan menggunakan metode penelitian dengan :

1. Pendekatan yuridis normatif 
Pendekatan yuridis normatif adalah metode penelitian hukum yang dilakukan dengan cara meneliti bahan pustaka atau data sekunder yang mencakup: ${ }^{3}$

a. Bahan Hukum Primer, yaitu bahan-bahan hukum yang mengikat, terutama yang berupa peraturan perundang-undangan. Dalam penelitian ini bahanbahan hukum primer yang digunakan adalah UUD 1945, KUHPerdata, Undang-Undang No. 5 Tahun 1960 tentang Peraturan Dasar Pokok-Pokok agrarian, Undang-Undang No. 4 Tahun 1996 tentang Hak Tanggungan, Undang-undang no. 10 Tahun 1998 tentang Perubahan Undang-undang No. 7 Tahun 1992 tentang Perbankan dan Peraturan pelaksanaannya seperti Peraturan Pemerintah, Peraturan Presiden, Peraturan Daerah dan lain-lain.

b. Bahan Hukum Sekunder, yaitu bahan hukum yang memberikan penjelasan tentang bahan hukum primer, antara lain berupa rancangan undang- undang, hasil penelitian, hasil karya dari kalangan hukum dan sebagainya. Dalam penelitian ini bahan hukum sekunder yang digunakan adalah buku- buku yang membahas mengenai jaminan dan hukum jaminan, jaminan kebendaan hak tanggungan, gadai, hipotik, hukum benda, hukum perikatan, hukum perbankan, filsafat dan teori hukum, serta buku-buku lainnya yang terkait dengan penelitian ini.

c. Bahan Hukum Tertier, yaitu bahan yang memberikan petunjuk maupun penjelasan terhadap bahan hukum primer dan bahan hukum sekunder, seperti kamus, ensiklopedia, indeks, surat kabar dan sebagainya.

2. Spesifikasi penelitian bersifat deskriptif analitis.

Penelitian yang bersifat deskriptif analitis dilakukan dengan menganalisa dan menguraikan secara lengkap dan menyeluruh sumber-sumber data sekunder yang diteliti.

\section{Hasil Penelitian dan Pembahasan}

\section{Unsur-unsur dalam Perjanjian Pokok dan Perjanjian Hak Tanggungan}

Perjanjian pokok merupakan perjanjian yang prinsipil, karena bersifat mandiri dan dapat berdiri sendiri oleh karenanya keberadaannya tidak bergantung pada perjanjian lain, bahkan tidak jarang lahirnya perjanjian pokok diikuti oleh lahirnya perjanjian lain. Sebagai suatu perjanjian yang bersifat mandiri dan dapat berdiri sendiri tentu tidak terlepas dari syarat sahnya suatu perjanjian sebagaimana yang disebutkan dalam pasal 1320 KUHPerdata, yaitu:

1) Sepakat mereka yang mengikatkann dirinya

Sepakat atau consensus yaitu merupakan keinginan bersama atau seiya sekata dari para pihak yang membuat perjanjian;

2) Kecakapan untuk membuat suatu perikatan

Kecakapan diatur dalam Pasal 1330 KUHPerdata yang menyebutkan orang yang tidak cakap membuat perjanjian adalah orang yang belum dewasa, wanita bersuami dan orang yang dibawah pengampuan;

\footnotetext{
${ }^{3}$ Soerjono Soekanto \& Sri Mamudji, Penelitian Hukum Normatif-suatu Tinjauan Singkat, PT. Grafindo Persada, Jakarta, 2001, hal. 13.
} 
3) Sesuatu hal tertentu

Sesuatu hal tertentu yaitu bahwa dalam perjanjian ada isi perjanjian yang mengatur hal tertentu atau tujuan tertentu yang hendak dicapai oleh para pihak;

4) Sebab yang halal

Sebab yang halal yaitu menyangkut isi perjanjian serta tujuan atau maksud diadakannya perjanjian tersebut adalah sepanjang tidak bertentangan dengan ketertiban umum, kesusilaan maupun undang- undang.

Dengan uraian di atas dapat dikatakan hahwa perjanjian pokok, merupakan perjanjian yang lahir dari adanya kesepakatan dri para pihak oleh karenanya sifatnya adalah :

1) Mandiri dan dapat berdiri sendiri sehingga yang dapat membatalkannya adalah apabila ketentuan dari pasal 1320 KUHPerdata tidak terpenuhi;

2) Perjanjian pokok dapat diikuti oleh perjanjian lainnya sebagai pelengkapnya sehingga keberadaannya merupakan sebagai induk dari perjanjian lain yang mengikutinya;

3) Keberadaannya berdasarkan pad kesepakatan yang dibuat para pihak;

4) Menganut asas terbuka, artinya siapapun dapat melakukan atau membuatnya asalkan harus didasarkan pada syarat sahnya perjnjian dan memperhatikan kepentingan umum dan tidak melanggar kesusilaan dan peraturan perundangundangan.

Hak Tanggungan yang dimaksud dalam Pasal 1 angka 91 UU hak tanggungan dalam pengertian ini dapat dikemukakan unsur Hak tanggungan, yaitu:

1) Hak tanggungan adalah hak jaminan untuk pelunasan utang tertentu;

2) Hak jaminan tersebut berkenaan dengan hak atas tanah berdasarkan UUPA berikut atau tidak berikut benda-benda yang merupakan satu kesatuan dengan tanah itu;

3) Hak Tanggungan memberikan kedudukan yanag diutamakan kepada krediturdebitur lainnya.

Unsur pertama berkenaan dengan Hak Tanggungan sebagai hak jaminan. Hak Tanggungan merupakan Hak Kebendaan. Hak Kebendaan merupakan hak mutlak atas sesuatu benda dimana hak itu memberikan kekuasaan langsung atas sesuatu benda dan dapat dipertahankan terhadap sispapun juga. Unsur Hak Tanggungan lainnya adalah pembebanan hak Tanggungan dituangkan dalam suatu akta yang merupakan satu kesatuan dan tidak dapat dipisahkan. Pemberian Hak Tanggungan dilakukan dalam suatu akta. Hal ini diatur dalam Pasal 10 ayat (2) UU Hak Tanggungan dalam pasal tersebut dinyatakan bahwa pemberian Hak Tanggungan dilakukan dengan pembuatan Akta Pemberian Hak Tanggungan oleh PPAT sesuai dengan peraturan perundang-undangan. Akta pemberian Hak Tanggungan merupakan suatu perjanjian yang tertulis. Sebagai hak jaminan, maka keberadaananya mengikuti perjanjian pokoknya atau hak jaminan kebendaan sebagai perjanjian yang bersifat accessoir. Hal ini telah ditegskan dalam Pasal 10 ayat (1) Undang-Undang Hak Tanggungan. 
Perjanjian pokok yang melahirkan perjanjian-perjanjian maka untuk memberikan jaminan harus merupakan perjanjian yang sah, dalam artian mengikuti perjanjian pokoknya, apabila perjanjian pokoknya dikatakan sah menurut pasal 1320 KUHPerdata maka perjanjian jaminan pribadi tersebut jauga merupakan perjanjian yang sah. Namun sebaliknya, apabila diketahui berdasarkan pada pasal 1321 KUHPerdata bahwa perjanjian pokoknya mengandung cacat hukum dan tidak sah maka perjanjian ikutannya yaitu perjanjian jaminan pribadi tersebut menjadi tidak sah pula dan dapat dituntut pembatalannya.

Perjanjian kredit merupakan perjanjian yang lahir dari perikatan yang tunduk dan diatur dalam ketentuan sebagaimana terdapat dalam buku III KUHPerdata. Perjanjian kredit merupakan salah satu usaha dalam perbankan yaitu memberikan pinjaman kepada pihak lain dimana dasar pemberian kredit ini merupakan pinjammeminjam sebagaimana diatur dalam KUHPerdata. Namun dalam pekembangannya diatur secara lebih luas dan rinci dalam Undang-Undang No. 10 Tahun 1998 tentang Perubahan atas Undang-Undang Nomor 7 Tahun 1992 tentang Perbankan serta peraturan lainnya dalam perbankan yaitu seperti Surat Keputusan Direksi Bank Indonesia No. 23/69/KEP/DIR tanggal 28 februari 1991 tentang Jaminan Pemberinan Kredit.

Perjanjian kredit harus diikuti dengan adanya suatu jaminan. Jaminan kredit tunduk pada ketentuan hak kebendaan yang diatur dalam buku II KUHPerdata. Dengan demikian segala penngaturan mengenai jaminan berdasar pada ketentuan dalam buku II KUHPerdata. Jaminan dalam kredit merupakan bentuk sebagai pelengkap dari perjanjian kredit itu sendiri oleh sebab itu sebagai pelengkap maka keberadaan perjanjian jaminan tergantung pada perjanjian pokoknya. Di sini terlihat bahwa perjanjian kredit adalah sebagai perjanjian pokok yang berdiri sendiri sedangkan perjanjian jaminan adalah pelengkapnya.

\section{Unsur-unsur yang terdapat dalam Asas Pelengkap}

Asas pelengkap dalam Hak Tanggungan diatur dalam Pasal 10 ayat (1) dan Pasal 18 ayat (1) UU hak Tanggungan, lebih lanjut Pasal 10 ayat (1) UU Hak tanggungan menyebutkan:

"Pemberian Hak Tanggungan didahului dengan janji untuk memberikan Hak Tanggungan sebagai jaminan pelunasan utang tertentun yang dituangkan di dalam dan merupakan bagian tak perpisahkan dari perjanjian utang-piutang yang bersangkutan atau perjanjian lainnya yang menimbulkan utang tersebut."

Dari rumusan di atas dapat dilihat bahwa unsur-unsur asas pelengkap dalam Hak Tanggungan adalah:

1) Keberadaannya bergantung pada perjanjian utang-piutang.

2) Keberadaannya harus merupakan ikutan dari perjanjian uang piutang;

3) Keberadaannya sebagai pelengkap atas jaminan pelunasan utang piutang;

4) Keberadaannya merupakan bagian tidak terpisahkan dari perjanjian utangpiutang yang bersangkutan atau perjanjian lainnya yang amenimbulkan utang tertentu.

Asas pelengkap merupakan suatu bentuk ikatan, di mana keberadaannya bergantung pada induknya, sehingga ada atau tidaknya bergantung kepada ada 
atau tidaknya induknya, asas pelengkap timbul karena jaminan hak kebendaan. Dalam jaminan kebendaan asas pelengkap berfungsi sebagai jaminan terhadap suatu perjajiian utang-piutang atau perjanjian kredit. Dalam hal perjanjian kredit hak tanggungan merupakan asas pelengkap dari perjanjian kredit tersebut.

Sesuai dengan asas dari Hak Tanggungan yaitu sebagai pelengkap, pemberiannya haruslah merupakan ikutan dari perjanjian pokok, yaitu perjanjian yang menimbulkan hubungan hukum utang-piutang yang dijamin pelunasannya. Perjanjian yang menimbulkan hubungan utang-piutang ini dapat dibuat dengan akta di bawah tangan atau harus dibuat dengan akta otentik, tergantung pada ketentuan hukum yang mengatur materi perjanjian itu. Dalam hal hubungan utang-piutang timbul dari perjanjian utang-piutang atau perjanjian kredit.

Berdasarkan uraian di atas, menurut penulis terdapat 2 (dua) hal terpenting dalam asas pelengkap, yaitu:

a. Perjanjian Hak tanggungan harus didahului denganjanji untuk memberikan hak Tanggungan;

b. Pembebanan Hak Tanggungan dituangkan dalam suatu akta yang merupakan satu kesatuan dan tidak dapat dipisahkan.

Perjanjian Hak tanggungan bukan merupakan perjanjian yang berdiri sendiri. Keberadaannya adalah karena adanya perjanjian lain yang disebut perjanjian induk. Dengan kata lain, perjanjian hak tanggungan adalah suatu perjanjian pelengkap. Oleh karena Hak Tanggungan menurut sifatnya merupakan ikutan atau pelengkap pada suatu piutang tertentu, yang didasarkan pada suatu perjanjian utang-piutang atau perjanjian lain, maka kelahiran dan keberadaannya ditentukan oleh adanya piutang yang dijamin pelunasannya.

Berdasarkan uraian di atas bahwa perjanjian Hak Tanggungan adalah suatu perjanjian pelengkap, karena dua hal, yaitu:

b. Perjanjian Hak Tanggungan merupakan bagian tak terpisahkan dari perjanjian utang yang bersangkutan;

c. Hak Tanggungan hapus karena hapusnya utang yang dijamin dengan Hak Tanggungan.

Dengan demikian bahwa jelaslah sebagai perjanjian pelengkap maka perjanjian hak tanggungan harus didahului dengan perjanjian kredit yang merupakan perjanjian pokok.

Oleh karena sebagai asas pelengkap. Maka keberadaannya tergantung dengan perjanjian pokok. Dalam hal ini bila perjnjian pokok hapus, maka hapus pula Perjanjian hak Tanggungannya, tetapi sebaliknya bila Perjanjian Hak tanggungan yang hapus, maka tidak menyebabkan perjanjian pokoknya juga hapus. Dengan demikian timbulnya Hak Tanggungan hanya dimungkinkan oleh UUHT dan KUHPerdata apabila sebelumnya telah diperjanjikan di dalam perjanjian utangpiutang yang menjadi dasar pemberian utang yang dijamin dengan Hak Tangguangan.

Akan tetapi dalam praktik di dunia perbankan yang terjadi adalah pembebanan Hak Tanggungan tanpa diawali dengan perjanjian pokok. Hal ini dibuktikan 
dengan adanya bank hipotik atau yang sekarang disebut dengan Hak Tanggungan bank yang merupakan jaminan yang diberikan oleh debitur sebagai pemberi jaminan untuk jaminan apa saja yang sekarang atau nantinya terhutang oleh pemberi jaminan atas dasar apapun juga. Berhubung dengan uraian tersebut, timbul pertanyaan bagaimana konsekuensi yuridis dari pembebanan Hak Tanggungan yang tidak didahului dengan perjanjian pokok yang melahirkan utang bersangkutan, tidak sahkah secara hukum Akta Pemberian Hak Tanggungan? Mengingat UU Hak tanggungan telah mengharuskan pembebanan hak Tanggungan didahului dengan perjanjian pokok, memang sudah seharusnya Hak Tanggungan yang dibuat sebaliknya tidak memiliki kekuatan hukum. Namun demikian kita tetap perlu memperhatikan perkembangan atau kebutuhan di masyarakat, sehingga sebelum menentukan Hak Tanggungan tidak sah secara hukum harus juga memperhatikan kebutuhan dalam praktik. Hal ini juga mengingat teori hukum pembangunan Muchtar Kusumaatmadja, yang menyebutkan hukum sebagai sarana pembangunan. Lebih lanjut mengenai penjelasan asas pelengkap dari Hak Tanggungan akan diberikan pembahasan selanjutnya dalam sub Bab di bawah ini.

\section{Analisa mengenai kedudukan Perjanjian Hak Tanggungan yang dibuat sebelum Perjanjian Pokok dikaitkan dengan Asas Pelengkap}

Dalam pembahasan ini penulis akan mengkaji bagaimana kedudukan pemberian Hak Tanggungan yang dibuat sebelum perjanjian pokok, dalam arti Hak Tanggungan tidak diperjanjikan dalam perjanjian pokok yang menimbulkan utang. Dalam Pasal 10 ayat (1) UU hak Tanggungan ditentukan:'..... di dalam dan merupakan bagian tak terpisahkan dari perjanjian utang-piutang yang bersangkutan atau perjanjian lainnya yang menimbulkan utang tersebut". Katakata tersebut menunjukkan bahwa janji pemberian Hak Tanggungan hanya dituangkan dalam perjanjian pokok yang menimbulkan Hak Tanggungan. Berdasarkan uraian di atas dapat disimpulkan bahwa janji pemberian Hak Tanggungan tidak boleh dituangkan dalam suatu akta yang terpisah dan berdiri sendiri, diluar perjanjian pokoknya.

Sebagai suatu perbandingan dalam hak jaminan hipotik yang dahulu berlaku bagi jaminan hak atas tanah, orang bisa untuk menjanjikan jaminan hipotik dengan menuangkan janji tersebut seperti dalam suatu akta tersendiri, yang biasa disebut dengan Surat Kuasa Untuk memasang Hipotik (SKMH). Dalam SKMH ada ditentukan bahwa para pihak atau pemberi kuasa sepakat untuk menganggap SKMH sebagai bagian dari perjanjian pokoknya, walaupun demikian akta tersebut tetap terpisah dari perjanjian pokoknya.

Ketentuan Pasal 10 ayat (1) UU Hak Tanggungan sebagaimana dimaksud di atas, bila diartikan dari kata-katanya, tidak mungkin menafsirkan sesuai dengan apa yang telah diuraikan di atas. Dengan demikian konsekuensi yuridisnya adalah Surat Kuasa Membebankan Hak Tanggungan (SKMHT) tidak diterima sebagai janji untuk memberikan Hak Tanggungan. Untuk diterima sebagai suatu janji yang demikian, maka harus dituangkan dalam perjanjian pokoknya. Dengan demikian bila kreditur lalai untuk memperjanjikan jaminan Hak Tanggungan, 
maka konsekuensinya adalah dia tidak berhak menuntut pemberian Hak Tanggungan. Namun demikian debitur atau pihak ketiga yang menjamin debitur tetap diberikan wewenang untuk memberikan Hak Tanggungan kepada kreditur. Selain permasalahan mengenai janji untuk memberikan Hak tanggungan yang harus dimuat dalam perjanjian pokoknya, terdapat juga masalah lain sepertiberkenaan dengan adanya pemberian Hak Tanggungan terlebih dahulu, sedangkan perjanjian pokoknya yang menimbulkan utang yang dijamin dengan Hak Tanggungan belum ada.

Perkembangan perkreditan dan lembaga jaminan saat ini disesuaikan dengan kebutuhan untuk menampung kebutuhan praktek dari apa yang pada waktu lalu disebut dengan Hipotik, Bank Hipotik adalah jaminan yang diberikan oleh debitur sebagai pemberi jaminan untuk menjamin apa saja yang sekarang atau nantinya terhutang oleh pemberi jaminan atas dasar apapun juga. Sekarang jaminan seperti itu disebut dengan Hak Tanggungan Bank. ${ }^{4}$ Perkembangan bank hipotik menjadi hak tanggungan Bank dapat dimengerti karena berlakunya hak jaminan kebendaan Hak Tanggungan bagi hak atas tanah yang sebelum lahirnya uu Hak Tanggungan masih menggunakan hak jaminan kebendaan hipotik.

Para Ahli seperti Scholten, Hofmann L.C dan Wawan Setiawan yang tidak melihat keberatan dan memungkinkan bahwa jaminan dalam hal ini termasuk juga Hak Tanggungan sebagai jaminan atas pelunasan hutang tertentu dapat diberikan untuk menjamin utang yang akan ada, bahkan sekalipun perjanjian yang akan melahirkan perikatan (utang-utang/kredit) tersebut pada saa jaminan diberikan belum lahir. Uraian di atas menunjukkan bahwa keberadaan Hak Tanggungan diperlukan untuk mengikuti perkembangan kebutuhan dalam praktik bank dan untuk memberikan kemudahan dalam pemberian kredit bank. Yang demikian itu sengaja diisyaratkan oleh kreditur, sebab khawatir, bahwa setelah perjanjian kredit ditandatangani dan uangnya telah diberikan kepada debitur, kemudian debitur ingkar janji untuk memberikan jaminan sebagai pelunasan utangnya, apabila debitur melakukan wasprestasi. Jadi sekalipun secara teoritis perjanjian jaminan merupakan perjanjian yang hidup dan mati bergantung dari perjanjian pokoknya dan karenanya bisa menimbulkan kesan mempunyai kedudukan yang kurang penting, namun dalam prakteknya, ia mempunyai peran yang sangat besar, bahkan sering kali justri perjanjian pokok baru bisa disetujui apabila jaminannya dinilai cukup hal ini seperti yang terdapat pada salah satu klausula pada perjanjian kredit pada salah satu Bank swasta di Indonesia pada pasal 11 menyebutkan bahwa "perjanjian kredit ini tidak pernah ada apabila tiak diikuti oleh adanya suatu jaminan dan yang nilai jaminan tersebut mencukupi nilai kredit”.

Yang demikian itu dilakukan oleh kreditur, sebab khawatir, bahwa setelah perjanjian kreditur ingkar janji untuk memberikan jaminan sebagai pelunasan utangnya. Jadi sekalipun secara teoritis perjanjian jaminan merupakan perjanjian yang hidup dan mati bergantung dari perjanjian pokoknya dan karenanya bisa

\footnotetext{
${ }^{4}$ J. Satrio, Hukum jaminan hak Jaminan Kebendaan Fiducia, Citra Aditya Bakti, Bandung, 2002, hlm. 163
} 
menimbulkan kesan mempunyai kedudukan yang kurang penting, namun dalam, prakteknya ia mempunyai peran yang angat besar, bahkan sering kali justru perjnjian pokok baru bisa disetujui apabila jaminannya dinilai cukup.

Namun dalam beberapa permasalahan yang mungkin timbul yaitu, kapan Hak Tanggungan lahir?, bukankah Hak tanggungan itu merupakan asas pelengkap?, sehingga hak tanggungan baru mempunyai daya kerja, kalau utang yang diberikan jaminan Hak Tanggungan sudah ada atau lahir/ Jadi akan mengalami gangguan, sehingga lebih jauh akan mengganggu stabilitas ekonomi nasional dan tujuan pembangunan nasional dan juga akan adanya ketidak seimbangan dan tidak ada kepastian hukum atau lemahnya kedudukan debitur, karena perjanjian hak tanggungannya telah diberikan terlebih dahulusementara perjanjian pokoknya belum dan dalam ini apabila dilihat dari segi itikad baik kreditur apabila kreditur mempunyai itikad tidak baik maka pihak debitur akan dirugikan.

Saat ini praktik pembebanan Hak Tanggungan yang perjanjian pokoknya melahirkan utang belum ada masih dapat dilakukan, walaupun UU Hak Tanggungan belum mengakomodasi kebutuhan praktik tersebut, yaitu seperti pada contoh. Hal ini dilakukan pihak bank untuk dapat menghemat waktu dan biaya. Namun demikian untuk mendukung teori hukum pembangunan, maka kebutuhan praktik tersebut harus segera diakomodasi dalam suatu peraturan perundangan atau dengan melakukan revisi UU Hak Tanggungan dan peraturan pelaksanaannya.

Namun demikian kebutuhan praktik tersebut di atas bila dikaitkan UndangUndang Hak Tanggungan No. 4 Tahun 1996 tidak dapat dibenarkan secara hukum, sebab Hak Tanggungan lahir atau baru memiliki daya kerja, bila utang yang dijamin dengan Hak tanggungan sudah ada. Hak Tanggungan mutlak harus dipatuhi, karena memang UU Hak Tanggungan menghendaki demikian, bahwa maksud dibuatnya ketentuan dalam UUHT tersebut lebih untuk memberikan jaminan kepastian dan perlindungan hukum khusus kepada debitur, sebab bila tidak demikian bagaimana halnya bila ternyata utang tidak terjadi sama sekali, sedangkan Hak Tanggungan telah dibebankan. Keadaan mungkin akan semakin buruk bila ternyata kreditur tidak memiliki itikad baik, apalagi bila Akta Pemberian Hak Tanggungan sudah dibuat dan ditandatangani para pihak dan di daftarkan di Kantor Pertanahan setempat, dengan demikian menurut UUHT bahwa perjanjian Hak tanggungan yang dibuat tanpa didahului oleh perjanjian pokoknya adalah perbuatan melawan hukum maka konsekuensinya perjanjian itu batal demi hukum. Hal yang sama dapat kita lihat pada pasal 1131 KUHPerdata yang menyebutkan :

"segala kebendaan si berutang, baik yang bergerak maupun yang tak bergerak, baik yang sudah ada maupun yang bru akan ada dikemudian hari menjadi tanggungan untuk segala perikatan perorangan."

Dalam KUHPerdata juga mengatakan bahwa segala benda milik debitur merupakan jaminan atau tanggungan dari perikatannya. Jadi adanya jaminan atau tanggungan berasal dari adanya perikatan yaitu utang atau krdit debitur, sehingga jaminan atau tanggungan itu keberadaannya berasal dari perikatan utang-piutang. 
Sehingga keberadaan jaminan atau tanggungan harus ada dasarnya yaitu perikatan atau perjanjian utang piutang, dengan demikian dalam KUHPerdata pun tidak mengakomodasikan bahwa jaminan atau tanggungan dapat diberikan lebih dahulu dari perjanjian utang-piutangnya.

Namun berbeda halnya dengan pembebanan hak tanggungan yang diberikan pada perjanjian kredit pertama namun dapat dibebankan pula pada perjanjian kredit berikutnya yang akan ada di kemudian hari, seperti yang terdapat dalam praktek disalah satu Bank Swasta di Indonesia di dalam salah satu klausul perjanjian kreditnya menyebutkan bahwa "mengenai pemberian kredit yang telah dan yang akan ada dengan demikian ketentuan bahwa mengenai syarat-syarat dan perjanjian-perjanjian yang akan ada tersebut, pihak kedua (bank) harus memberitahukannya kepada pihak prtama (debitur)". Dari uraian di atas dapat digambarkan bahwa jaminan hak tanggungan yang telah didaftarkan tersebut dapat juga menjadi jaminan bagi perjanjian kredit berikutnya atau yang akan ada. Di sini dapat dilihat bahwa hak tanggungan tersebut telah dibebankan sebagai jaminan kredit berikutnya, dengan demikian Hak Tanggungan telah dibebankan untuk kredit yang berikutnya hal ini menggambarkan bahwa pembebanan Hak tanggungan yang telah diberikan pada perjanjian kredit pertama dapat dibebankan pula pada perjanjian kredit berikutnya yang akan ada di kemudian hari. Hal ini menurut Undang-Undang Hak Tanggungan hal seperti ini dapat dibenarkan. Menurut pasal 5 ayat (1) UUHT menentukan bahwa suatu objek Hak Tanggungan dapat dibebani lebih dari satu Hak Tanggungan guna menjamin pelunasan lebih dari satu utang. Pembebanan terhadap lebih dari satu utang dalam UUHT disebut peringkat Hak Tanggungan. Peringkat Hak Tanggungan ini bertujuuan untuk adanya hak-hak kreditur yang didahulukan dari kreditur lain, oleh karenanya peringkat Hak Tanggungan didaftarkan berdasarkan tanggal Akta Pemberian Hak Tanggungan, apabila akta pemberian Hak Tanggungan terebut dibuat pada tanggal yang sama maka peringkat Hak Tanggungan ditentukan oleh nomor urut Hak Tanggungan. Dan bila dikaitkan dengan asas pelengkap maka uraian di atas tersebut dapat dibenarkan karena perjanjian hak tanggungan sebagai aturan yang terpisah yang merupakan bagian dari aturan pokoknya (perjanjian pokoknya) sesuai dengan asas pelengkap sehingga peraturan yang dibuat secara tersendiri itu dapat dilaksanakan sebagaimana peraturan pokoknya dan berlaku serta mengikat bagi masing- masing pihak yang membuatnya.

Lebih lanjut Pasal 10 ayat (1) UU Hak Tanggungan menyebutkan:

"Pemberian Hak Tanggungan didahului dengan janji untuk memberikan Hak tanggungan sebagai jaminan pelunasan utang tertentu yang dituangkan di dalam dan merupakan bagian tak terpisahkan dari perjanjian utang-piutang yang bersangkutan atau perjanjian lainnya yang menimbulkan utang tersebut."

Dengan melihat uraian di atas maka apabila dikaitkan dengan perjanjian maka asas pelengkap merupakan suatu petunjuk dan penyempurna dari suatu perjanjian pokok. Jadi jelaslah bahwa hak tanggunngan merupakan bagian dari asas pelengkap, yang ada atau lahirnya dan hapusnya bergantung pada perjanjian pokoknya yaitu perjanjian utang-piutang atau kredit dengan melihat unsur-unsur asas pelengkap yang tedapat dalam hak tanggungan tersebut di atas maka 
keberadaan hak tanggungan harus didahului oleh perjanjian pokoknya yaitu perjanjian utang-piutang atau perjanjian kredit. Dengan demikian berdasarkan pada pasal tersebut di atas maka apabila pemberian Hak Tanggungan lebih dahulu dilakukan daripada perjanjian pokoknya maka asas pelengkap tersebut dilanggar.

Berdasarkan penjelasan di atas dapat dikemukakan dua masalah pokok seputar pembahasan ini, yaitu pertama kebutuhan praktik di dunia perbankan atau umumnya bagi kebutuhan pembangunan ekonomi nasional memerlukan efektivitas dan efisiensi waktu dan biaya, tetapi dalam hal ini hukum tidak atau belum mengakomodasi kebutuhan tersebut. Kedua mengenai tujuan dan fungsi hukum secara khusus untuk mendorong dan mengarahkan pembangunan sebagai tujuan dari hukum modern, sedangkan bila dikaitkan dengan masalah di atas, hukum melalui peraturan perundang-undangan belum mencapai tujuan tersebut, karena masih belum mengakomodasikan kebutuhan praktik di masyarakat.

Teori hukum pembangunan yang dikemukakan oleh Muchtar Kusumaatmadja mengemukakan bahwa hukum tidak boleh ketinggalan dengan proses perkembangan yang terjadi di dalam masyarakat. Pembangunan yang berkesinambungan menghendaki adanya konsepsi hukum yang selalu mampu mendorong dan mengarahkan pembangunan sebagai cerminan dari tujuan hukum modern. Konsep tersebut kemudian dimodifikasi menjadi hukum sebagai sarana pembangunan (1976). Sebagai impementasi dari arah kebijakan tersebut di atas, pemerintah menetapkan program perencanaan hukum yang ditujukan untuk menciptakan persamaan persamaan persepsi dari seluruh pelaku pembangunan khususnya di bidang hukum dalam menghadapi berbagai issu strategis dan global yang secara cepat perlu diantisipasi agar penegakan dan kepastian hukum tetap berjalan secara berkesinambungan. Dengan program ini diharapkan akan dihasilkan kebijakan atau materi hukum yang sesuai dengan aspirasi masyarakat, baik pada saat ini maupubn masa mendatang, mengandung perlindungan dan penghormatan terhadap hak asasi manusia serta mempunyai daya laku yang efektif dalam masyarakat secara keseluruhan.

Bila dikaitkan dengan permasalahan di atas, maka setiap kebijakan pemerintah atau materi hukum yang dibuat berkenaan dengan Hak Tanggungan dan hubungannya dengan perjanjian pokok, harus memenuhi unsur sosiologis, yaitu materi hukum yang dibuat harus sesuai dengan aspirasi atau kebutuhan masyarakat pada saat ini atau pada masa yang akan datang. Hal ini dilakukan agar peraturan yang dibuat memiliki daya yang efektif dalam masyarakat.

\section{E. Kesimpulan}

Dari hasil penelitian yang penulis lakukan, sebagai jawaban dari permasalahan yang menjadi objek penelitian, maka dapat diambil beberapa kesimpulan sebagai berikut:

a. Unsur-unsur dalam perjanjian kredit sama dengan unsur-unsur yang terdapat dalam perjanjian pokok dengan demikian dapat dikatakan bahwa perjanjian kredit merupakan perjanjian pokok, unsur-unsur itu yaitu : menganut asas 
terbuka, artinya siapapun dapat melakukan atau membuatnya asalkan harus didasarkan pada syarat sahnya perjanjian dan memperhatikan kepentingan umum dan tidak melanggar kesusilaan dan peraturan perundang-undangan mandiri sehingga yang dapat membatalkannya adalah apabila ketentuan dari pasal 1320 KUHPerdata tidak terpenuhi, dan perjanjian pokok dapat diikuti oleh perjanjian lainnya sebagai pelengkap sehingga keberadaannya merupakan sebagai induk dari perjanjian lain yang mengikutinya. Pembebananan terhadap Hak Tanggungan harus dituangkan dalam pejanjian Hak Tanggungan. Keberadaan perjanjian hak tanggungan karena adanya perjanjian lain yang disebut dengan perjanjian pokok yaitu perjanjian kredit. Dengan kata lain perjanjian hak tanggungan adalah perjanjian pelengkap, sehingga hapusnya atau berakhirnya perjanjian hak tanggungan bergantung pada perjanjian pokok.

b. Asas pelengkap merupakan aturan terpisah yang dibuat oleh para pihak yaitu debitur dan kreditur secara tersendiri, sebagai penyempurna suatu perjanjian dan dalam penerapan dan pelaksanaannya tetap harus berdasarkan kesepakatan kedua belah pihak yakni debitur dan kreditur, dengan demikian asas pelengkap berlaku bagi perjanjian hak tanggungan karena perjanjian hak tanggungan bersifat asseccoir atau ikatan dari perjanjian pokoknya bila dikaitkan dengan asas pelengkap maka keberadaan hak tanggungan merupakan aturan pelengkap atau penyempurna dari perjanjian pokok.

c. Berdasarkan KUHPerdata, dalam pasal 1131 KUHPedata maka jelaslah bahwa perjanjian utang piutang (kredit) harus lebih dahulu ada dari perjanjian hak tanggungan sebagai jaminan atas utang (kredit) tersebut dan apabila dilihat dari asas-asas perjanjian itu sendiri sebagaimana yang diatur dalam KUHPerdata sebagai acuan dasar dari segala perjanjian maka perjanjian Hak Tanggungan yang dibuat sebelum perjanjian pokok tidak dapat dilakukan mengingat bahwa dalam memberikan Hak Tanggungan sebagai jaminan harus juga memperhatikan kepastian dan perlindungan hukum bagi debitur. Bila dikaitkan Undang-Undang Hak Tanggungan bahwa perjanjian Hak Tanggungan yang dibuat tanpa didahului oleh perjanjian pokoknya adalah perbuatan melawan hukum maka konsekuensinya perjanjian itu batal demi hukum. Berbeda halnya dengan pembebanan hak tanggungan yang telah diberikan pada perjanjian kredit pertama namun dapat dibebankan pula pada perjanjian kredit berikutnya yang akan ada di kemudian hari hal ini menurut Undang-Undang hak Tanggungan hal seperti ini dapat dibenarkan. Dan bila dikaitkan dengan asas pelengkap maka uraian di atas tersebut dapat dibenarkan karena perjanjian hak tanggungan sebagai aturan yang terpisah yang merupakan bagian dari aturan pokoknya (perjanjian pokoknya) sesuai dengan asas pelengkap sehingga peraturan yang dibuat secara tersendiri itu dapat dilaksanakan sebagaimana peraturan pokoknya dan berlaku serta mengikat bagi masing-masing pihak yang membuatnya. 


\section{DAFTAR PUSTAKA}

\section{Buku}

Hoffmann, L.C. Het nedrkandsch Verbinteniessen rech, Jilid II, de Bijzondere overeenkomsten. cetakan pertama, J.B. Wolers Groningen, Batavia, 1936.

J. Satrio. Hukum jaminan hak Jaminan Kebendaan Fiducia, Citra Aditya Bakti, Bandung, 2002.

Muhammad Abdulkadir. Hukum Perdata Indonesia, PT. Citra Aditya Bakti, Bandung, 1993.

Soerjono Soekanto \& Sri Mamudji. Penelitian Hukum Normatif-suatu Tinjauan Singkat, PT. Grafindo Persada, Jakarta, 2001.

\section{Bahan Hukum}

Perjanjian-perjanjian Kredit dari Lembaga Keuangan Perjanjian-perjanjian Kredit dari Notaris

Perjanjian Hak Tanggungan.

\section{Peraturan Perundang-Undangan}

Undang-Undang Nomor 10 Tahun 1998 tentang Perubahan atas UndangUndang Nomor 7 Tahun 1992 tentang perbankan.

Undang-Undang Nomor 4 Tahun 1996 tentang Hak Tanggungan

Rancangan Undang-Undang Perkreditan Perbankan 